University of Nebraska - Lincoln

DigitalCommons@University of Nebraska - Lincoln

USDA National Wildlife Research Center - Staff Publications
U.S. Department of Agriculture: Animal and Plant Health Inspection Service

5-18-2007

\title{
Stress Response of Working African Elephants to Transportation and Safari Adventures
}

Joshua J. Millspaugh

University of Missouri, Columbia, joshua.millspaugh@umontana.edu

Tarryne Burke

University of KwaZulu-Natal, South Africa

Gus Van Dyk

University of KwaZulu-Natal, South Africa

Rob Slotow

University of KwaZulu-Natal, South Africa

Brian E. Washburn

United States Department of Agriculture, Wildlife Services, National Wildlife Research Center, brian.e.washburn@aphis.usda.gov

See next page for additional authors

Follow this and additional works at: https://digitalcommons.unl.edu/icwdm_usdanwrc

Part of the Environmental Sciences Commons

Millspaugh, Joshua J.; Burke, Tarryne; Van Dyk, Gus; Slotow, Rob; Washburn, Brian E.; and Woods, Rami J., "Stress Response of Working African Elephants to Transportation and Safari Adventures" (2007). USDA National Wildlife Research Center - Staff Publications. 726.

https://digitalcommons.unl.edu/icwdm_usdanwrc/726

This Article is brought to you for free and open access by the U.S. Department of Agriculture: Animal and Plant Health Inspection Service at DigitalCommons@University of Nebraska - Lincoln. It has been accepted for inclusion in USDA National Wildlife Research Center - Staff Publications by an authorized administrator of DigitalCommons@University of Nebraska - Lincoln. 


\section{Authors}

Joshua J. Millspaugh, Tarryne Burke, Gus Van Dyk, Rob Slotow, Brian E. Washburn, and Rami J. Woods 


\title{
Stress Response of Working African Elephants to Transportation and Safari Adventures
}

\author{
JOSHUA J. MILLSPAUGH, ${ }^{\mathbf{1}}$ Department of Fisheries and Wildife Sciences, University of Missouri, 302 Natural Resources Building, Columbia, MO \\ 65211, USA \\ TARRYNE BURKE, Amarula Elephant Research Programme, School of Biological and Conservation Sciences, University of KwaZulu-Natal, Durban \\ 4041, South Africa \\ GUS VAN DYK, Amarula Elephant Research Programme, School of Biological and Conservation Sciences, University of KwaZulu-Natal, Durban 4041, \\ South Africa, and North West Parks and Tourism Board, Pilanesberg National Park, Mogwase, South Africa \\ ROB SLOTOW, Amarula Elephant Research Programme, School of Biological and Conservation Sciences, University of KwaZulu-Natal, Durban 4041, \\ South Africa \\ BRIAN E. WASHBURN, United States Department of Agriculture, Wildlife Services, National Wildlife Research Center, Sandusky, OH 44870, USA \\ RAMI J. WOODS, Department of Fisheries and Wildlife Sciences, University of Missouri, 302 Natural Resources Building, Columbia, MO 65211, USA
}

\begin{abstract}
African elephants (Loxodonta africana) are intensively managed in southern Africa and are routinely translocated between reserves. Domesticated elephants are used for elephant-back safaris and interactions with guests. Understanding how elephants respond to such activities is critical because of welfare issues associated with both humans and elephants. We investigated the stress response (i.e., fecal glucocorticoid metabolite secretion [FGM]) of working elephants in Letsatsing Game Reserve, South Africa, over 1 year to evaluate their response to transportation and ecotourism activities. We used free-ranging elephants in adjacent Pilanesburg National Park as controls. Fecal glucocorticoid metabolites were greatest prior to and during translocation and declined over the year. Within 1-2 months of transportation, FGM levels in working elephants became indistinguishable from those in wild elephants. Fecal glucocorticoid metabolite levels were higher during human interaction days than days without interaction. The highest observed FGM levels were associated with transportation and episodic loud noises. Transportation is a stressful activity for elephants, and $\geq 3$ months should be provided to translocated elephants to acclimate to their new surroundings. Although stress levels of elephants increased slightly when interacting with humans in the contexts we studied, evaluating interactions under a wider range of contexts is necessary to minimize danger to elephants and humans. (JOURNAL OF WILDLIFE MANAGEMENT 71(4):1257-1260; 2007)
\end{abstract}

DOI: $10.2193 / 2006-015$

KEY WORDS ecotourism, elephant, human disturbance, South Africa, stress hormones, translocation.

In the early 1980s, park managers in South Africa and adjacent countries culled African elephant (Loxodonta africana) herds to remove excess individuals. Managers translocated many of the remaining juveniles to parks and reserves to establish new populations; others were relocated to private sanctuaries. However, translocated juveniles created difficulties as they matured. Juvenile male elephants that were translocated to parks and reserves without adult male elephants bred successfully by 18 years and entered musth unusually early for extended periods (Slotow et al. 2000). Between 1991 and 2000, these elephants killed $>100$ white rhino (Ceratotherium simum) and 5 black rhino (Diceros bicornis) in Pilanesberg National Park (Slotow and van Dyk 2001) and Hluhluwe-Umfolozi Park (Slotow et al. 2002). Elephants that were domesticated outgrew private sanctuaries. Releasing them into the wild was not feasible because they were hand-raised by humans. Some of these elephants are being used to carry out elephant-back safaris in areas with and without other wild elephants.

These working elephants provide popular, but controversial, ecotourism activities in South Africa. Understanding how elephants respond to such activities is critical because of welfare issues associated with both humans and elephants. For example, safaris may stress working elephants (i.e., cause increased glucocorticoid secretion), which could compro-

${ }^{1}$ E-mail: Millspaughj@missouri.edu mise immune function, resistance to disease, and survival if stress is chronic (Dunlap and Schall 1985, Wingfield and Farner 1993, Sapolsky et al. 2000). Moreover, stressed animals behave differently, which could have dire consequences when animals are in routine contact with humans; such elephants have killed $\geq 2$ people.

In light of these issues, we investigated fecal glucocorticoid metabolites (FGMs) as a measure of stress response of 5 elephants translocated to and used during safaris in the Letsatsing Game Reserve in South Africa over a 1-year period to determine whether these activities are stressful to elephants. For comparison, we simultaneously measured FGMs in wild elephants.

\section{STUDY AREA}

The Letsatsing Game Reserve was located in the North West Province of South Africa. The reserve, which was surrounded by an electric fence, encompassed 450 ha and bordered Pilanesburg National Park on the northern and eastern sides. The area was a major ecotourism destination and was situated adjacent to Sun City and the Lost City Complex, a 2-hour drive from Johannesburg, South Africa. The reserve consisted of mixed woodlands with interspersed stands of Acacia thickets and areas of open grassland.

The 5 working elephants used in the reserve were orphaned at 2-3 years as a result of herd reductions in the 1980s. After being raised on private farms, these 5 elephants 
were eventually moved to the Elephant Camp in Victoria Falls where their training was completed. All elephants were transported to the reserve in early September 2002. The elephant-back safaris and tourist interaction with the elephants commenced in December 2002.

Safaris were conducted on the reserve in early mornings and late afternoons. The elephants fed naturally between activities and often interacted across the fence with adjacent wild elephants in Pilanesburg National Park. Also, meals were offered where guests interacted with the elephants.

\section{METHODS}

To evaluate the annual stress profiles of the 5 elephants in Letsatsing (working elephants), we collected an average of 79 fresh $(<24$-hr-old) fecal samples (range $=72-83, n=$ 396) from each elephant between 1 September 2002 and 13 September 2003. We collected samples: 1$)<4$ days before travel, 2) day of travel, 3) 2-7 days after travel, 4) 8-14 days after travel, 5) 15-29 days after travel, 6) 1-2 months after travel, 7) 3-4 months after travel, 8) 5-6 months after travel, 9) 7-8 months after travel, 10) 9-10 months after travel, and 11) 11-12.5 months after travel. Initially, we collected fecal samples more frequently to allow us to evaluate immediate short-term responses to transportation.

We also initiated intensive sampling that involved collection of all fecal material from working elephants over 6 24-hour periods. Of the 6 24-hour sampling periods, 3 occurred when the 5 elephants had no interaction with humans and 3 occurred when elephants interacted with tourists during afternoon events or were used for safaris. We also recorded the presence of other potentially stressful events, such as episodic noises (e.g., lightning). Because there is a delay of about 24-36 hours from the time of a stressful event until detection of increased FGM levels in elephant feces, we considered stressors 24-36 hours from the previous day in our evaluation of stress data (Wasser et al. 2000). In other words, when relating FGM levels to disturbances, we recognized that stress hormones contained within a sample were a result of stress hormone secretion 24-36 hours previously (Millspaugh et al. 2001). For comparison, we also obtained fresh fecal samples from wild male and female elephants in Pilanesburg National Park (wild elephants) during the same time periods (10-15 samples/month).

We shipped frozen fecal material overnight to the University of Missouri for FGM analysis. We treated samples with a $2 \%$ acetic acid solution prior to shipment to kill potential pathogens and prevent disease transmission (Millspaugh et al. 2003). After arrival, we freeze-dried, ground, and sifted each sample through a stainless steel mesh. We extracted FGM from elephant feces using a modification of Schwarzenberger et al. (1991) described by Wasser et al. (2000).

We used corticosterone $\mathrm{I}^{125}$ radioimmunoassay (RIA) kits (MP Biomedicals, Costa Mesa, CA) to quantify elephant FGM concentrations. We followed the MP Biomedicals protocol for the corticosterone $I^{125}$ RIA, except that we halved the volume of all reagents, which is standard practice (Wasser et al. 2000). We conducted a standard assay validation, including assessment of parallelism, recovery of exogenous analyte, intra- and inter-assay precision, and assay sensitivity (Jeffcoate 1981, Grotjan and Keel 1996, O'Fegan 2000), to confirm the assay accurately and precisely measured FGM in elephant feces. Inter-assay variation for 5 assays was $6.8 \%$ and average intra-assay variation was $3.1 \%$.

We compared intensively sampled FGM data on days when elephants interacted with humans with days they did not using a paired $t$-test (Zar 1996).

\section{RESULTS}

Fecal glucocorticoid metabolites were greatest prior to and during translocation and declined over the year. For example, average FGM levels prior to and up to 1 month after translocation were roughly double the mean values observed during any other sampling period (Fig. 1). Within 1-2 months of transportation, FGM levels in working elephants became indistinguishable from those of wild elephants (Fig. 1).

We observed variation in FGM levels between days when elephants interacted with humans and those days they did not. Fecal glucocorticoid metabolite levels were higher during human interaction days $(\bar{x}=27.8 \mathrm{ng} / \mathrm{g}, \mathrm{SD}=10.7, n$ $=97)$ than days without interaction $(\bar{x}=22.9 \mathrm{ng} / \mathrm{g}, \mathrm{SD}=$ 8.3, $n=96 ; t=34.1, \mathrm{df}=192, P<0.001)$.

The highest observed FGM levels were associated with transportation and episodic loud noises. The 2 highest FGM values (170.8 $\mathrm{ng} / \mathrm{g}$ and $103.5 \mathrm{ng} / \mathrm{g}$ ) corresponded with transportation. The next highest values $(93.6 \mathrm{ng} / \mathrm{g}$, $77.3 \mathrm{ng} / \mathrm{g}$, and $76.4 \mathrm{ng} / \mathrm{g}$ ) corresponded to lightning and thunderstorm events and a concert that included fireworks (90.4 ng/g and $76 \mathrm{ng} / \mathrm{g}$ ).

\section{DISCUSSION}

Although transportation and initial stimuli were stressful, elephants quickly acclimated, as evidenced by decreased FGM levels. Early experience of these animals and their prior translocations and interactions with one another might have further modified the stress response (Moberg 2000). The acclimation time allowed also likely contributed to the response of these animals (Moberg 2000).

Transportation was an important acute stressor for these elephants, as evidenced by the correspondingly high FGM levels related to that activity. Based on the results of an adrenocorticotropin (ACTH) challenge conducted by Wasser et al. (2000), values of $90 \mathrm{ng} / \mathrm{g}$ should be considered high and indicate a stressed elephant. We observed even higher values for elephants during transportation, although the typical value was about $65 \mathrm{ng} / \mathrm{g}$, indicating an elevated stress response (Wasser et al. 2000). Transportation has long been recognized as an important stressor in domestic and wild animals (e.g., Kannan et al. 2000, Zapata et al. 2004). It is important that animals not be exposed to additional stressors initially after transport because those additional 


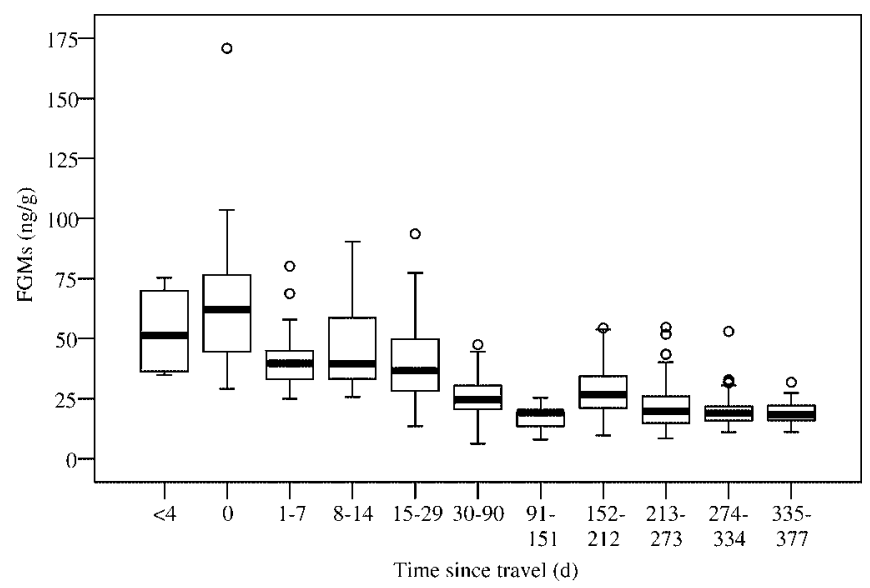

(B)

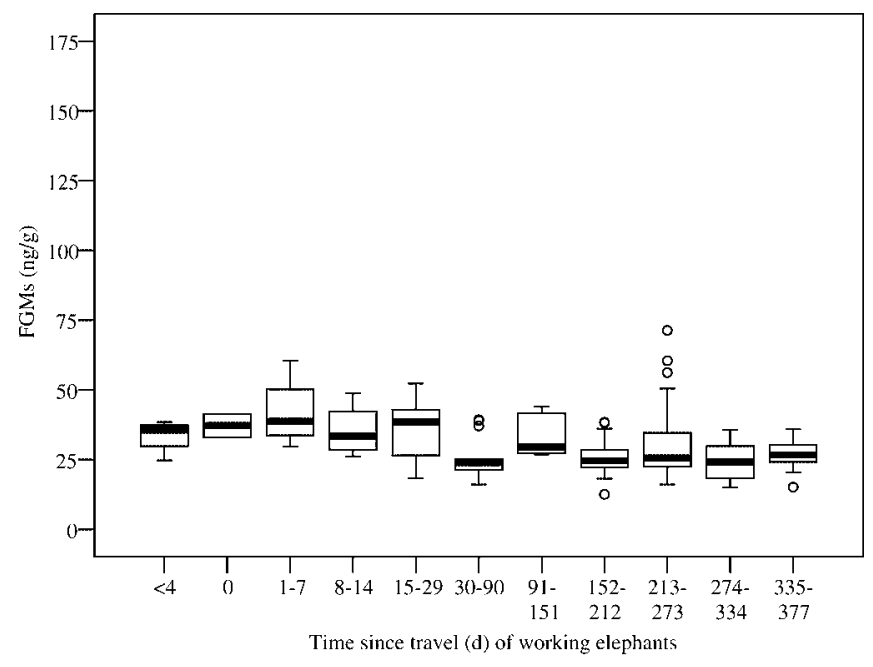

Figure 1. (A) Box plot of fecal glucocorticoid metabolite (FGM) secretion of hand-reared African elephants before, during, and after translocation to Letsatsing Game Reserve, South Africa, 2002-2003, and (B) box plot of FGM of wild African elephants in adjacent Pilanesburg National Park, South Africa, 2002-2003. The upper and lower edges of the box indicate the 75 th and 25 th percentiles, respectively, of the data set. The line within the box indicates the median value of the data set. The ends of the vertical lines extend to a maximum of 1.5 times the inter-quartile range. The points outside the vertical lines are suspected outliers.

stressors might result in additional biological cost, and thus could prove harmful to the animal (Moberg 2000).

The use of elephants for ecotourism activities has occurred in places like Thailand for decades, but the activity is still controversial. In Letsatsing, elephants became accustomed to use as working elephants, as evidenced by their annual FGM profile. Fecal glucocorticoid metabolite levels were higher during days when elephants interacted with humans, but the average increase of $4.9 \mathrm{ng} / \mathrm{g}$ was likely not biologically relevant based on ACTH challenge results (Wasser et al. 2000, Millspaugh and Washburn 2004), which suggests a $20 \mathrm{ng} / \mathrm{g}$ increase would be biologically meaningful.

\section{MANAGEMENT IMPLICATIONS}

We offer the following recommendations to those managing working elephants: 1) elephants will be stressed during transportation, and external stressors (e.g., noise) and transportation time should be reduced, 2) providing translocated elephants $\geq 3$ months to acclimate to their new surroundings should help reduce stress levels, 3) allowing elephants to interact with one another after transportation might provide an important behavioral distraction and reduce stress, 4) monitoring stress is a useful diagnostic tool in understanding elephant responses to human activities and time to acclimation (Stead et al. 2000, Foley et al. 2001, Ganswindt et al. 2003) under various conditions, and 5) although stress levels of elephants increased slightly when interacting with humans in the contexts we studied, evaluating interactions under a wider range of contexts is necessary to minimize danger to elephants and humans.

\section{ACKNOWLEDGMENTS}

We thank B. Mitchell, who supervises the care and guidance of these elephants, for his cooperation and assistance. We are grateful to D. Atwill of Columbia, Missouri, USA, for introductions leading to collaborative research projects between the University of Missouri (MU) and the University of KwaZulu-Natal. The MU South African Partnerships Program and the MU Alumni Association provided grant support of this research. T. Burke's salary was paid by PPC Cement, and field work was conducted under the auspices of the Amarula Elephant Research Programme (funded by Distell). R. Steidl and 2 anonymous reviewers provided helpful comments.

\section{LITERATURE CITED}

Dunlap, K. D., and J. J. Schall. 1985. Hormonal alterations and reproductive inhibition in male fence lizards (Sceloporus occidentalis) infected with the malarial parasite Plasmodium mexicanum. Physiological Zoology 68:608-621.

Foley, C. A. H., S. Papageorge, and S. K. Wasser. 2001. Noninvasive stress and reproductive measures of social and ecological pressures in freeranging African elephants. Conservation Biology 15:1134-1142.

Ganswindt, A., R. Palme, M. Heistermann, S. Borragan, and J. K. Hodges. 2003. Non-invasive assessment of adrenocortical function in the male African elephant (Loxodonta africana) and its relation to musth. General and Comparative Endocrinology 134:156-166.

Grotjan, H. E., and B. A. Keel. 1996. Data interpretation and quality control. Pages 51-93 in E. P. Diamandis and T. K. Christopoulos, editors. Immunoassays. Academic Press, New York, New York, USA.

Jeffcoate, S. L. 1981. Efficiency and effectiveness in the endocrinology laboratory. Academic Press, New York, New York, USA.

Kannan, G., T. H. Terrill, B. Kouakou, O. S. Gazal, S. Gelaye, E. A. Amoah, and S. Samake. 2000. Transportation of goats: effects of physiological stress responses on live weight loss. Journal of Animal Science 78:1450-1457.

Millspaugh, J. J., and B. E. Washburn. 2004. Use of fecal glucocorticoid metabolite measures in conservation biology research: considerations for application and interpretation. General and Comparative Endocrinology 138:189-199.

Millspaugh, J. J., B. E. Washburn, M. A. Milanick, R. Slotow, and G. van Dyk. 2003. Effects of heat and chemical treatments on fecal glucocorticoid measurements: implications for sample transport. Wildlife Society Bulletin 31:399-406.

Millspaugh, J. J., R. J. Woods, K. Hunt, K. J. Raedeke, B. E. Washburn, G. 
C. Brundige, and S. K. Wasser. 2001. Using fecal glucocorticoids to quantify the physiological stress response of free-ranging elk. Wildlife Society Bulletin 29:899-907.

Moberg, G. P. 2000. Biological response to stress: implication for animal welfare. Pages 1-21 in G. P. Moberg and J. A. Mench, editors. The biology of animal stress. CABI, New York, New York, USA.

O'Fegan, P. O. 2000. Validation. Pages 211-238 in E. P. Diamandis and T. K. Christopoulos, editors. Immunoassays. Academic Press, New York, New York, USA.

Sapolsky, R. M., L. M. Romero, and A. U. Munck. 2000. How do glucocorticoids influence stress responses?: integrating permissive, suppressive, stimulatory, and adaptive actions. Endocrine Reviews 21: $55-89$.

Schwarzenberger, F., E. Möstl, E. Bamberg, J. Pammer, and O. Schmehlik. 1991. Concentrations of progestagens and oestrogens in the faeces of pregnant Lipizzan, Trotter and Thoroughbred mares. Journal of Reproduction and Fertility Support 44:489-499.

Slotow, R., D. Balfour, and O. Howison. 2002. Killing of black and white rhinoceros by African elephant in Hluhluwe-Umfolozi Park, South Africa. Pachyderm 31:14-20.

Slotow, R., and G. van Dyk. 2001. Role of delinquent young "orphan" male elephants in high mortality of white rhinoceros in Pilanesberg National Park, South Africa. Koedoe 44:85-94.
Slotow, R., G. van Dyk, J. Poole, B. Page, and A. Klocke. 2000. Older bull elephants control young males. Nature 408:425-426.

Stead, S. K., D. G. A. Meltzer, and R. Palme. 2000. The measurement of glucocorticoid concentrations in the serum and faeces of captive African elephants (Loxodonta africana) after ACTH stimulation. Journal of the South African Veterinary Association 71:192-196.

Wasser, S. K., K. E. Hunt, J. L. Brown, K. Cooper, C. M. Crockett, U. Bechert, J. J. Millspaugh, S. Larson, and S. L. Monfort. 2000. A generalized fecal glucocorticoid assay for use in a diverse array of nondomestic mammalian and avian species. General and Comparative Endocrinology 120:260-275.

Wingfield, J. C., and D. S. Farner. 1993. Endocrinology of reproduction in wild species. Avian Biology 9:163-327.

Zapata, B., J. Gimpel, C. Bonacic, B. Gonzalez, J. Riveros, A. Ramirez, F. Bas, and D. W. Macdonald. 2004. The effect of transport on cortisol, glucose, heart rate, leukocytes, and body weight in captive-reared guanacos (Lama guanicoe). Animal Welfare 13:439-444.

Zar, J. H. 1996. Biostatistical analysis. Third edition. Prentice Hall, Upper Saddle River, New Jersey, USA.

Associate Editor: Steidl. 